\title{
Is corporate governance a first-order cause of the current malaise?
}

\author{
JEFFREY N. GORDON
}

Abstract: The US has evolved a regime of high-powered corporate governance in which managerial performance is disciplined through shareholder value metrics. This paper argues against over-stating the importance of this regime in creating problems of inequality, greater economic insecurity, and slower economic growth. Corporate governance acts principally as the transmission mechanism to the behaviour of the particular firm of changes in the global and domestic competitive environment. The critical problem is a risk-shift from shareholders, who now have access to robust diversification against firm-specific risks, and towards employees, whose concentrated firm-specific investments are hard to protect or diversify. The paper argues that we need a different government-private sector 'match' for the development of human capital, shifting away from a purely k-12 (or k-16+) model of government subsidy to a model that takes account of the need to replenish human capital over a lifetime. Such a strategy is not only distributionally appealing, but also pro-growth, since it revitalises human productivity.

Keywords: Corporate governance, shareholder value, human capital, inequality, economic insecurity.

\section{EXECUTIVE SUMMARY}

The United States, indeed much of the OECD, is facing a 'triad' of three salient problems: significant inequality; economic insecurity; and slow economic growth. In the search for causes and remedies, some have identified the governance of large public corporations as a first-order cause.

For example, US Democrat Senator Elizabeth Warren has recently proposed an 'Accountable Capitalism Act' based on the view that relentless maximisation of shareholder value has caused many of America's fundamental economic problems. The remedy is a corporate governance solution involving co-determination for all companies with revenues over $\$ 1$ billion, with at least 40 per cent of the directors selected by employees. 
This paper argues there are important corporate governance elements in inequality and economic insecurity but not in slow economic growth. It offers a board reform that could enhance financial inclusion and could perhaps lead to some additional growth. Its most far-reaching proposal calls for a new government-private sector 'match' in human capital renewal.

The most important consequence of corporate governance changes since the 1980s has been a risk-shift in the adjustment costs of economic change from shareholders to employees. Shareholders have had access to effective vehicles for diversification, but employees' firm-specific investments are harder to diversify. Firms have reduced job security for employees and shrunk guaranteed pension payouts tied to employmentbased wage levels.

The principal reason for these shifts is an increasingly competitive environment with global product markets and capital markets. Pressures also come from domestic disrupters which have upended retail distribution networks of goods, entertainment, and media. These forces have forced adaptations within many firms on cycles that are shorter than the career-span of most employees, leaving few companies with the capacity to provide the 'thick' insurance packages conducive to human well-being.

The paper proposes a new form of subsidy or 'public endowment' between the government and private sector, with lifetime advanced training and retraining to give employees the freedom to choose careers and life plans, and provide an initial allocation of bargaining power.

This 'insurance' may help address the risk of skills obsolescence, a modern form of dis-ability that calls out for socialisation. Risk-diversification techniques have given shareholders protection against firm-specific risks. Owners benefit from growth in the economy as a whole, irrespective of whether particular firms are diminished or even survive. Employees simply cannot effectively diversify against these risks.

The author does not call for redistribution, or simply an effort to assure that gains that increase the whole pie do not result in smaller slices for many. Rather, a long-term strategy is needed to address adverse demographic trends and the increasing mismatch between tax receipts and the cost of social benefits.

Enhancing ongoing productive capacity will enlarge the labour force. The classic defence of downsizing and lay-offs is not that it increases shareholder value, but that it frees up scarce resources. Given the specialised training that many good jobs require, a government-backed lifetime retraining programme offers the promise of high dividends.

There is also the need for innovations in boards. For example, the present board model is not well suited for companies whose projects and business strategy may be difficult for equity market analysts to evaluate. Independent directors may lack the skills to serve as credible monitors of management's strategy and operational performance. 
This governance shortfall may provide an economic reason both for high levels of executive compensation and for the growth of the private company equity market relative to the public equity market. The development of a new, optional Board 3.0 governance model consisting of 'thickly informed' directors with deep commitments, will be more credible with investors. It would be optional for firms whose business model justified the extra monitoring costs. A Board 3.0 option would make public markets more inviting, which would enhance financial inclusion and growth in public companies. By contrast, mandatory co-determination for the boards of all US companies is likely to degrade US economic performance.

\section{INTRODUCTION}

The United States, indeed much of the OECD, seems caught in a certain malaise. Take three salient problems, the 'triad': significant inequality; economic insecurity; and slow economic growth. In the search for causes and remedies, some have identified the governance of large public corporations, 'corporate governance', as a first-order cause.

Indeed, one example of the belief in the importance of corporate governance is the recent legislative proposal of Senator Elizabeth Warren, a possible 2020 US presidential candidate. The 'Accountable Capitalism Act' is premised on the view that that the shift to shareholder primacy, maximising shareholder value, 'is the root cause of many of America's fundamental economic problems.' This shift, she argues, has resulted in large-scale shareholder payouts that 'otherwise would have gone to workers or long-term investment', reducing what otherwise would have been significant wages gains or resulting in 'chronic underinvestment' by big US companies, 'opening the door to foreign competitors'. The appropriate remedy is a corporate governance solution, specifically US-style co-determination for all companies with revenues over $\$ 1$ billion, with at least 40 per cent of the directors selected by employees.

This paper argues that there are important corporate governance elements in inequality and economic insecurity, and corporate governance changes could ameliorate these factors to some extent. One important change relates to the board of directors. The present board model, framed by academic theorising about the 'monitoring board' nearly forty years ago, is not well suited for companies whose projects and business strategy may be difficult for equity market analysts to evaluate. The 'independent directors' who serve on the current board model may be insufficiently informed and committed to serve as credible monitors of management's strategy and operational performance. This governance shortfall may provide an economic reason both for high levels of executive compensation and for the growth of the private 
company equity market relative to the public equity market. The development of a new governance model, 'Board 3.0', consisting of 'thickly informed' directors with deep commitments, will be credible with investors. Such a board could handle executive compensation differently and, by sheltering hard-to-reveal strategies in the public company space, would expand economic opportunities for public investors. This would enhance financial inclusion. The Board 3.0 model would be optional for firms whose business model justified the extra monitoring costs. But one should not overstate the value of this governance reform in addressing the triad.

By contrast, requiring co-determination for the boards of all significant US companies is likely to degrade US economic performance. The practicalities of selecting employee representatives is more than an inconvenience. The conflicting interests of differently situated employees goes to the core of the inefficiencies. At given points in the economic cycle, the demand for one group's skills may escalate; for another group, deteriorate. Under the pressure of multiple constituency demands, the board becomes a vehicle for dividing the pie (and minimising losses) rather than growing the pie, particularly if some may lose. This is hardly a prescription fort enhancing the economic dynamism and capacity of public corporations. In an important example of codetermination in a large US corporation, the United Airlines employee buyout of the early 1990s, these conflicts - which brought gridlock to the board-were the proximate cause of the airline's bankruptcy a few years later. This cost employees collectively their 55 per cent stake in the airline's profits (Gordon 1998, 2003). Germany's success with co-determination has little relevance for the US because of different institutional pre-conditions, including strong national unions that select employee representatives, a two-tiered board structure in which the co-determined 'supervisory board' has a more limited role than the typical US board, and sectoral bargaining, which removes some conflictual issues from board decision-making. The most valuable feature of German co-determination may well be a complementary institution, the 'works council' that facilitates labour-management cooperation within the firm, not board representation (Adams \& Deakin 2018).

The most important consequence of the corporate governance changes in the US since the 1980s is risk-shifting of the adjustment costs of economic change from shareholders to employees. Shareholders have access to increasingly effective vehicles for diversification. An asset management industry has arisen that specialises in producing low-fee, robustly diversified portfolios of equity securities. Employees' firm-specific investments are much harder to diversify. Firms over the period have provided increasingly thinner packages of social insurance, as measured through both reduced job security for employees and the steady shrinkage of guaranteed pension payouts tied to employment-based wage levels. The principal reason for these shifts is an increasingly competitive environment in which firms operate, in light of global product markets and capital markets. The thick 'insurance' packages provided by US 
firms in the halcyon 1950s were to a significant extent made possible by a high level of economic rents that US firms could provide in the aftermath of World War II. The corporate governance changes complained of in Senator Warren's account, entrenched by the 1980s, were galvanised by the slack performance at US firms, as revealed by the quick inroads by German and Japanese competitors in major areas of US industrial production, such as automobiles.

But the ongoing competitive threat to incumbents is not only the consequence of global product and capital markets. The pressures come from domestic disrupters as well, which, in the contemporary US include companies like Walmart, Amazon, Netflix, and the social media companies, which have in a short period of time upended prior retail distribution networks of goods, entertainment, and media. These ongoing economic forces, global and domestic, have predictably forced adaptations within many firms on cycles that are shorter than the career-span of most employees. Indeed, the lifespan of many firms has been (and will continue to be) shorter than the careerspan of the employees. This environment leaves few firms with the capacity to provide the 'thick' insurance packages that are conducive to human well-being.

This then is the backdrop for this paper's proposal for a new form of 'match' between the government and private sector enterprise. It has been customary to expect that core human capital investments - literacy, numeracy, and advanced training in many sub-disciplines - will be provided, funded, or otherwise subsidised by government. This government subsidy for training that in many cases could be provided by private firms has complementary power within the overall economic system. Among other features, what might be thought of as the 'public endowment' in human capital development gives employees freedom to choose careers and life plans and provides an initial allocation of bargaining power. Changes in the economic environment argue for an ongoing match between the government and productive enterprise, a replenishing of this endowment, a match that focuses on the possibilities for re-education and retraining over a lifetime.

Government subsidy on this dimension can be thought of as a new kind of insurance, one that addresses the risk of skills obsolescence, a modern form of disability. Firms will have limited capacity to provide this kind of insurance; most individuals will be unable to self-insure against this risk. Moreover, firms that attempt to offer robust economic insurance may thereby attract a relatively risk-averse workforce, which could undermine its competitive success. This is a kind of risk that calls out for socialisation. The modern technology of risk diversification has given shareholders protection against firm-specific risks. Shareholders can benefit from growth in the economy as a whole, irrespective of whether particular firms are diminished or even survive. Employees simply cannot effectively diversify against these risks; they will not necessarily benefit from growth in the economy as a whole, and attention must be paid. 
This point can be framed differently, in a way that makes clear that this proposal does not collapse into a call for redistribution, or simply an effort to assure that gains that increase the whole pie do not result in smaller slices for many. Rather: One of the explanations for the low economic growth rate is the adverse demography. The percentage of the working population is declining relative to those who are living longer; this produces an increasing mismatch between tax receipts and the payout of retirement income and health benefits. Enhancing the ongoing productive capacity of people is one way to enlarge the labour force. The classic defence of downsizing and lay-offs is not that they increase shareholder value for the particular firm. Instead, they free up scarce resources for firms that put those resources to better use. Given the practical barriers to seamless switching in the labour market, including particularly the specialised training that many good jobs require, a lifetime re-education and retraining programme offers the promise of high dividends. As a strategy, 'Invest in our People' is one way out of the malaise.

\section{AN INITIAL COMPLICATION: WHAT IS CORPORATE GOVERNANCE?}

To hazard the conjecture that 'corporate governance' could be a 'cause' of anything, some initial specification seems in order. As a general matter, 'corporate governance' refers to the allocation of decision-making power and influence within the corporation. Corporate governance is hardly static, since different allocations of decision-making power-in-fact can evolve even if the underlying legal regime framework is relatively static (Gilson 2018). In the United States, for example, the basic legal structure, in which shareholders obtain power through the periodic election of directors, who are responsible for management (or oversight of management) of the corporation, has remained unchanged over several decades. Nevertheless, changes in the pattern of ownership and developments in capital markets have dramatically changed the functional implications of the legal set-up. A shift in public equity ownership from diffuse retail owners to asset managers and other institutional investors has empowered 'shareholders' and correspondingly reduced the autonomy of management (the CEO) and has both strengthened the board (relative to the CEO) and diminished the board (relative to shareholders). These ownership shifts were driven by factors outside of the legal framework for corporate governance: the growth of retirement savings, the internationalisation of capital markets, and a move towards 'diversification' as an investment style (Gilson \& Gordon 2013). Still, the consequence for 'corporate governance' has been enormous. As described below, the discretion of management to persistently pursue strategies that are not aimed at increasing the welfare of shareholders is limited. Moreover, institutional shareholders commonly measure 'shareholder welfare' in terms of the market price of the stock. 
Indeed, since the 1950s and 1960s, perhaps the heyday of retail stock ownership in the US, there have been four distinct overlapping shifts in ownership, each with implications for corporate governance. The first is the general shift from retail ownership to institutional ownership, fuelled by (i) the rise of mutual funds targetted to retail investors and (ii) the rise of public and private defined benefit plans that held securities as collateral for contractual pension promises. The second was a further concentration of ownership into the hands of a relatively small number of asset managers, who hold appreciable stakes in a large fraction of public companies. The third was the increasing level of foreign ownership of US public equity, now in the 25-30 per cent range. The fourth was the increasing shift from active to passive management by institutional investors, now approximately 30 per cent of US public equity.

The 'reconcentration' of ownership reduces collective action costs that otherwise would consign shareholders to 'rational apathy' in corporate governance matters. One immediate corporate governance consequence is that management is much more exposed to challenge by activist shareholders who have no intention to bid for the firm. In the 1950s and 1960s proxy contests were (with rare exceptions) an ineffective way for an activist to challenge management's strategy or operational skill. The dispersion of shareholders made communication difficult and costly; activists also found it hard to establish a 'reputation' for creating value for all shareholders rather than for pursuing control to obtain private benefits. The hostile tender offer of the 1970s-1980s can be understood as a mechanism devised to surmount these collective action barriers, but of course such a bid was very costly and often provoked great resistance. With reconcentration, proxy battles have become a viable strategy. The activist can target a relatively small number of institutional investors and proxy advisors. Because such investors are repeat players, an activist can develop a reputation for value creation and not private benefits extraction.

Ownership reconcentration has also permitted investors to challenge management even without an activist catalyst, through what might be called 'aggressive passive' strategies: 'Just Vote No' in the case of director nominees or no-votes on 'Say on Pay' matters. These strategies can signal discontent with the particular matter in question, such as compensation levels or structure, but can also indicate dissatisfaction with management's general performance.

The increase in foreign portfolio holdings means that a sizable group of shareholders are unlikely to be moved by appeals to national US interests (apart from the business case in assessing such appeals). The increase in the fraction of passive ownership increases the percentage of shareholders who will pursue 'voice'-based governance strategies rather than 'exit'. It will necessarily make more influential the shareholders who pursue 'active' strategies with respect to firm-specific governance initiatives because of the possibility of tapping into discontented shareholders who are nevertheless locked into ownership positions. 
Note that with rare exception (the 'Say on Pay' provisions of the Dodd-Frank Act), these very substantial changes in corporate governance have occurred without significant change to the underlying laws. Changes in ownership have been the fundamental driver of corporate governance in-fact.

One of the ongoing questions is the plasticity of corporate governance: Is it always and necessarily the case that the ownership pattern that has evolved will produce an outcome that promotes 'shareholder interests', as reflected exclusively in terms of the stock price? For example, as will be explored in more detail below, asset managers may be thought of as creating financial products that consist of low-cost diversified portfolios of risky assets. The nature of the diversification is to eliminate idiosyncratic risk, but that leaves systematic risk as a critical performance variable. The effort to improve risk-adjusted returns would require asset managers to focus on strategies that might increase expected returns across the economy reflected in the diversified portfolio. Similarly, asset managers could focus on sources of systematic risk. What might this mean in practice? What would it mean to promote shareholder interests in general instead of on a firm-by-firm basis? Presumably institutional investors already pursue some elements of this policy in favouring certain normative conceptions of corporate governance-one-share, one-vote; single-class boards; annual say-on-pay votesbecause they believe this enhances the value of their portfolios as a whole, rather than make (costly) firm-specific assessment. Are there other elements of normative corporate governance that they should favour on these grounds? Are there extra-corporate governance policies that they might well promote on a similar rationale?

\section{AN INITIAL DISTINCTION: CORPORATE GOVERNANCE OF FINANCIAL FIRMS AND NON-FINANCIAL FIRMS}

Failures in corporate governance were correctly seen as a major cause of the financial crisis, but the corporate governance of important financial firms is a distinct problem separate from the governance of the non-financial firms that make up the 'real' economy. This is because the failure of a large financial firm registers differently from the failure of a non-financial firm, which in turn calls for a different corporate governance mindset. The failure of a large financial firm could well be a 'systemic' event, meaning that the negative consequences of its failure would extend beyond its shareholders and creditors and could damage the 'real' economy. Thus a bank's shareholders will get the upside of the bank's risk-taking, but the costs of failure will ramify throughout the financial sector into the real economy. The different models can be seen through the lens of the 'business judgement rule', which protects directors from liability for mistaken, even negligent, business decisions that are undertaken in good faith. 
The general goal is to encourage business risk-taking, understanding that many reasonable business ventures will fail, given the nature of competitive enterprise. This model naturally lends itself to high-powered compensation for managers and employees, to encourage the risk-taking that shareholders (who have the capacity to diversify) would prefer. This corporate governance model is a misfit for large financial firms, however, because it encourages risk-taking irrespective of the systemic costs of failure. In short, the corporate governance failure associated with the financial crisis was in part an intellectual failure: the failure to see that the optimal failure rate of the largest financial firms is zero because of the systemic downside.

Banks are highly leveraged. Their balance sheets are, by construction, relatively opaque; the combination of opacity and leverage means that asset substitution can rapidly change the riskiness of the bank before shareholder or other private monitors can intervene. Historically much of the funding for bank balance sheets was provided by short-term creditors. Wholesale creditors relied on the nimbleness of their exit to sidestep the bank's troubles rather than on corporate governance. Retail depositors, who generally lack monitoring capacity, depended upon government-provided deposit insurance not the bank balance for their security. In the crisis run-up, shareholders' pressure for 'performance' and the associated high-powered managerial incentives exploited these monitoring gaps as part of the banks' business strategy. Thus in the years before the financial crisis, shareholders were approving of compensation arrangements that encouraged risk-taking by managers and employees throughout the bank. The risk-taking governance model that is generally appropriate for nonfinancial firms is a poor fit for financial firms.

In the immediate crisis aftermath, some called for more aggressive shareholder monitoring of managerial risk-taking, not yet appreciating that shareholder cheerleading encouraged banks to add on risk to match the performance of risk-taking peers and was a crisis-accelerator. Subsequent scholarship revealed the mismatch between the governance model for financial firms and non-financial firms (Armour \& Gordon 2014). In general, post-crisis financial regulation has taken on excess risktaking by financial firms more directly through balance-sheet controls and activity restrictions, rather than attempting wholesale corporate governance innovation. For example, boards of large US financial firms are required to have risk committees; in the EU, regulations have targetted variable compensation arrangements, trying to modify risk-taking incentives. But most of the work to address the distinctive safety and soundness needs of financial institutions is done through direct regulation rather than corporate governance. 


\section{THE TRIAD: INCOME INEQUALITY, ECONOMIC INSECURITY, SLOW ECONOMIC GROWTH}

Corporate governance has been implicated in each of these current policy and political issues: income inequality, economic insecurity, and slow economic growth. This paper's view is that corporate governance has had a contributory role with respect to income inequality. High levels of executive compensation are in part the result of weak board structure at a critical time in the evolution of compensation patterns and also reflect shareholders' accommodations to the Delaware courts' anti-takeover regime. A flawed board model has also been one impetus for take-private transactions, which have resulted both in outsize pay-offs to a very small group and problems of financial inclusion.

Shareholder-focused corporate governance has been a factor in increasing economic insecurity, but second order, since corporate governance is principally the conveyer belt of enhanced competitive pressures in the real economy. Since the sources of competitive pressure often arise outside of US public companies, it is not clear the extent to which shareholder-focussed corporate governance has independent effects: whether public company governance is a major source of additional competitive pressure. That is a possibility.

The case that shareholder-focused corporate governance has significantly contributed to slow economic growth, by encouraging firms to engage in stock buy-backs that have produced underinvestment in plant, employees, and innovation, is weak. The evidence is that public companies generally have ample access to internal and external finance to pursue available investments. The related claim that shareholder-influenced corporate governance is a major source of so-called 'short-termism' seems, as a general matter, hard to sustain. The macro-environment cannot be ignored. An economic environment in which fundamental economic and political questions seem unsettled hardly invites 'longterm' planning. The question also seems mis-specified, since the optimal time horizon seems the one that best fits the company's business, including the product cycle of competitors and the nature of the required investment. A utility that is contemplating building an electricity generating plant obviously must engage in different calculation from a consumer products company. It is certainly the case, however, that a particular firm could get it wrong on either the short-side or long-side of the planning horizon.

\section{INCOME INEQUALITY}

Corporate governance has affected income inequality on at least three vectors: executive compensation; gains received by partners and limited partners of private equity firms; and the declining share of enterprise profits that goes to employees, the 'labour share'. 


\section{Executive compensation}

Corporate governance has played a significant role in (i) the shift to stock-based compensation and (ii) 'golden parachute' severance agreements that produce very large payouts for target managements when triggered in merger transactions. Both of these elements have been factors in a sharp rise in managerial pay as symbolised by the very high ratio of CEO to median employee pay reported in new public disclosures of public company compensation. These compensation levels arose because of flaws in the US corporate governance model, exacerbated by actions of the Delaware courts. US corporate governance has improved, but path dependency makes it very hard to change compensation expectations. Because of the size and importance of US firms, the US compensation pattern has become the 'market' throughout much of the OECD.

Stock-based pay became entrenched for US public corporations in the 1990s and has now become the major way in which compensation is paid for senior executives. 'Dot.com' firms in the 1990s commonly used large stock option grants to pay senior executives, particularly as a recruitment device for executives at established firms. The practice rapidly spread to other public companies, in part because the prevailing accounting treatment did not require the 'expensing' of so-called 'plain vanilla' options (meaning: simple options with an exercise price above the current market price-'out of the money'; options that were indexed to performance measures did not qualify for this treatment). Since the options were not 'expensed' - did not reduce reporting earnings - the options appeared to be 'free', even though of course their exercise would dilute the shareholders' claim on the firm (Murphy 2013). It became common for an executive to receive a large option package that would vest over a multi-year period. ${ }^{1}$

At the same time firms also began to provide special severance arrangements for senior executives who lost their jobs in a takeover transaction, or even in the event of takeover where the executives retained their jobs. These 'golden parachutes' included the immediate payout of a multiple of annual base salary (typically approximately $3 \times$, because of a tax penalty for a greater payout) and the accelerated vesting of previously granted options. Since the deal price was commonly at a substantial premium to the option exercise price, large option grants combined with the accelerated vesting feature could deliver quite substantial payouts, even for executives who were replaced for underperformance. Taking capital gains into account, CEOs commonly receive an immediate payout that is ten to sixteen times their pre-merger annual cash compensation (depending on the calculative method used) (Hartzell et al. 2004).

\footnotetext{
${ }^{1}$ In the mid-2000s other forms of stock-based pay entered the picture, in part because stock prices did not rise as rapidly as during the 1990s and because of accounting changes that requiring the expensing of stock options, promoting a shift to grants of restricted stock (Bebchuk \& Fried 2004).
} 
The common way to frame the debate over executive compensation is to oppose two models: managerial power (Bebchuk \& Fried 2004), or optimal contracting (Kaplan 2012; see Edmans \& Gabaix 2016). These models have a certain static quality that does not capture the dynamic by which compensation practices were formed and sustained, an evolutionary process on the model of a punctuated equilibrium, in which the factors of corporate governance, contagion, and path dependency have played a large role. The move to stock-based pay was not just a fad picked up from the dot.coms; it solved a corporate governance problem associated with the relatively weak board model of the 1980s and 1990s. Boards at the time were shifting from an advisory board model, Board 1.0, staffed by insiders and the CEO's trusted outside advisors, to a monitoring board model, Board 2.0, staffed principally by independent directors (Gordon 2007). These independent directors were 'thinly informed', meaning that their part-time engagement and 'outsider' status limited both their firm-specific information and their monitoring tools. But given the rich disclosure by public companies and 'efficiency'-promoting trading markets, the directors could regard the stock price as a useful measure of managerial performance. It permitted both ownfirm comparisons over time (for example, this year over last year) and cross-sectional comparisons (this firm versus others in the sector). Stock-based pay, especially stock options, solved the problem of how to incentivise management to produce the superior performance that directors could readily observe. Moreover, since options were 'free', meaning, the Black-Scholes value of the options granted did not reduce current earnings per share under the applicable accounting rules, directors could think that high option grants would generate a self-enforcing monitoring scheme that advanced shareholder interests.

The irony, of course, is that having decided that the stock price was a 'sufficient statistic' to judge managerial performance, the board could have used many forms of variable compensation to achieve the incentive effects. Indeed, even a fixed wage that was conditional on achieving a certain level of stock price performance would deliver strong incentives. The threat of dismissal for failing to achieve a certain level of stock performance may be a strong incentive. And, of course, the options were in fact costly: when exercised they reduced earnings per share. Stock buy-backs in many cases reflect an effort to stabilise the number of shares outstanding in light of such exercises and thus to preserve the same level of earnings per share (and protect the stock price); this is where actual cash may be expended for the benefit of management (Fried 2011). Thus the weak governance at the time led to a certain confusion about stock-based pay for its incentive effects as opposed to a kind of profit-sharing with shareholders. Assume that managerial effort leads to outstanding performance: what is the 'just desert' level of the sharing? Pay to induce performance is not the same as pay given performance (Gordon 2005). 
Golden parachutes arose because of a different corporate governance weakness. The Delaware courts of the late 1980s and early 1990s gave managements and boards a 'Just Say No' prerogative when confronted with a hostile bid. This came through permission for the board to adopt a 'poison pill' in the form of a shareholder rights plan that would massively dilute the ownership position of a bidder that crossed a sub-control ownership threshold without the board's consent. This gave rise to significant dissatisfaction among the institutional investors, then constituting approximately 35 per cent of public company shareholders. Rejection of a premium bid deprived target shareholders of the immediate merger gains. Although the Board 2.0 structure featured 'independent directors', the prevailing legacy culture would make it difficult for boards to overcome management's rejection of a hostile bid. Golden parachutes solved the dissonance between managerial and shareholder objectives; because of the option acceleration feature, a triggered 'chute' could make senior managers truly rich. In effect, golden parachutes represented a shareholder buyback of the takeover resistance endowment granted to managers by the Delaware courts, made necessary by boards too weak to have an independent view of the virtues of a sale. ${ }^{2}$

Because of the size and international penetration of the US firms, US compensation levels and structure become the international standard (Thomas 2009). The early flaws in US corporate governance thus spread virally (see Acharya \& Volpin 2014). Even though US corporate governance has significantly improved (active board monitoring, the reconcentration of ownership) and the say-on-pay mandate of the DoddFrank Act of 2010 provides a potentially corrective channel, the path dependency of compensation structure and levels have been a formidable barrier to change. Changes would be registered as a 'loss', and as, as behavioural law and economics teach (Kahneman \& Twersky 1979), would be fiercely resisted. The persistence of golden parachutes exemplifies this. Boards have evolved into something like a 'Board 2.5' framework: not only are directors formally independent, but over time have become more independent (from management) and more sensitive to the interests of shareholders, especially major shareholders. The willingness of directors to relinquish the protections of board classification reflects this. It would now be the rare case in which boards would permit management to turn down a premium bid. What then, is the point of golden parachutes? Management's takeover resistance endowment has been

\footnotetext{
${ }^{2}$ The corporate governance system that produced outsized executive compensation included the complaisance of the Delaware Courts, which sheltered compensation payouts through narrowly defined fiduciary duties and procedural devices that closed off possible litigation challenges to compensation levels. For a road not taken, see, for example, Thomas and Wells (2011).
} 
eroded through subsequent corporate governance changes, yet path dependency would make it very hard to revoke a very lucrative element in executive compensation. This is so even though golden parachutes may yield a lottery pay-off that creates a strong sense of 'inequality', particularly since 'synergy gains' in mergers often entail significant employee lay-offs. Indeed, path dependency has created such a strong sense of managerial entitlement that in a significant fraction of cases managements are able to obtain enrichments of the parachute pay-off while negotiating a sale of the firm (Choi et al. 2018). ${ }^{3}$

\section{Private equity compensation}

Some of the original work on income inequality focussed on comparisons between the income shares of the top 1 per cent and cohorts below, finding the top 1 per cent receiving a growing share of national income. In this regard, Piketty and others regarded growing levels of executive compensation as a major source of inequality (Piketty 2014, Piketty \& Saez 2003, Saez 2008). In the US this is partly right but mostly wrong. It is mostly wrong because the evidence is the disproportionate share of the income gains in the US are going not to the top 1 per cent but rather the very top, the top 0.01 per cent and 0.001 per cent. The post-tax income growth over the 1980-2014 period was 194 per cent for the top 1 per cent, but 423 per cent for the top 0.01 per cent and 616 per cent for the top 0.001 per cent (Piketty et al. 2018). In 2012, the cut-off for the top 1 per cent was $\$ 372,000$, for the top 0.01 per cent, $\$ 7.2$ million (Guvenen \& Kaplan 2017). This group is receiving income not through 'executive compensation', but through flow-through vehicles that reflect returns to privately owned businesses (Smith et al. 2017), and the profits of private equity and venture capital firms (Preqin 2018), which flow through to the partners and limited partners of those ventures.

Although the outsize compensation earned by leading private equity (PE) and venture capital (VC) firm executives are headline news, the earnings of PE and VC employees are only part of the inequality story. PE and VC assets under management were $\$ 3$ trillion as of mid-2018 (Preqin 2018). Approximately $\$ 1$ trillion is 'dry powder', meaning that $\$ 2$ trillion is invested. The profitability of the PE/VC model has led

\footnotetext{
${ }^{3}$ The efficiency case for golden parachutes rests on assumptions that undercut the general case for stock-based executive compensation. CEO efforts to pursue merger transactions that would benefit shareholders may well be unobservable (unlike instances in which the CEO attempts to block an announced bid), so that sharing of the merger gains through a parachute payment may overcome an agency problem (Holmstrom 1979). But the performance outcomes from ongoing business operations (unlike preliminary merger overtures) will be disclosed and thus impounded in a measure (the stock price) that the directors can observe.
} 
to many new entrants, and of course the 'average' fund performance will converge on the performance of general stock markets. But many PE/VC firms are extraordinarily successful in earning outsize returns. The retail investor is simply excluded from participation in the possibility of earning these returns. Yes, some institutional investors (public pension funds and university endowments) whose beneficiaries may be retail investors or even non-investors, can participate, but in general some of the most lucrative returns in the real economy are captured by the top 0.01 per cent or top 0.001 per cent. Another way to measure the diversion of opportunity is this: assume a median internal rate of return of 14 per cent (Preqin 2018: 11) and discount rate of 5 per cent. This means that the implicit market value of PE investments would be roughly $\$ 8$ trillion. The market cap of US stock markets is approximately $\$ 30$ trillion dollars. Thus retail investors are frozen out of more than 20 per cent of the market, including some of the companies where growth opportunities and expected returns are highest.

What is the corporate governance connection? Shortfalls in the public company governance model look to be a significant reason for 'take-private' transactions, for mid-size companies' pursuit of PE financing instead of going public ('stay private'), and similarly the avoidance of public markets by many VC-backed companies (also 'stay private'). In other words, weak corporate governance has produced financial exclusion. As explained above (and developed in Gilson \& Gordon (2018)), the public company governance model is based on a board that consists of thinly informed directors whose chief monitoring insight and tool (stock-based pay) relies on stock market prices. For firms that cannot reveal their strategies for competitive reasons (they would lose first-mover advantages) or where there is a complicated 'story', the stock price may not fully reflect the firm's value. Yet thinly informed directorstime-constrained, resource-constrained, knowledge-constrained-will not be able credibly to attest that management is picking the optimum strategy or is a superior operator, should the firm be challenged by activists who may have done deep research into the firm and its industry. The institutional investors who are the majoritarian owners of these firms will not look to directors as credible adjudicators of disputed business claims between management and activists. This then may push firms off the optimal investment path. A take-private transaction (or, in anticipation, a 'stayprivate' transaction) may become the preferred alternative, because well-resourced, expert monitors with skin in the game will bring superior valuation skills. The PE governance model can provide much deeper monitoring capacity and thus create additional value both through strategic enablement and superior operations. A better board model for public companies, 'Board 3.0', which includes well-resourced, wellinformed, and well-compensated directors, would open up a new option for public companies and permit a broader sharing of gains from superior performance: the 
financial inclusion of public shareholders. 'Board 3.0' should be developed as an option for the special firms with the opportunities that would warrant higher cost monitoring.

\section{The 'labour share'}

The 'labour share' of enterprise rents has been declining for more than fifteen years in the United States. It declined in the early 1990s, rose to historical baselines by the end of the 1990s, but has been declining ever since. See Figure 1. This has generally confounded economists, who, following Keynes, thought of the stability of the labour share as 'one of the surprising, yet best-established, facts in the whole range of economic statistics' Keynes (1939). One of the particular features of the post-2000 period has been the growth in the gap between the increases in productivity and increase in wages (Dao et al. 2017, Giandrea \& Sprague 2017) (a global phenomenon). These empirical aggregates seem to coincide with other indicia of a secular increase in inequality. At the most basic level, if labour is getting less, than capital must be getting more. Since share ownership is generally concentrated in the top two income deciles of the population, increases in percentile rank, dividends, and stock repurchases will add to income inequality (Wolff 2010: Table 15b).

A question that cannot be resolved here is the weight that 'corporate governance' should receive in accounting for this decline in the labour share. For example, among other important factors seems to be the decline in private sector unionisation, which has eroded employees' bargaining endowments, and a generally more intensely competitive environment in certain business sectors, as discussed more generally below.

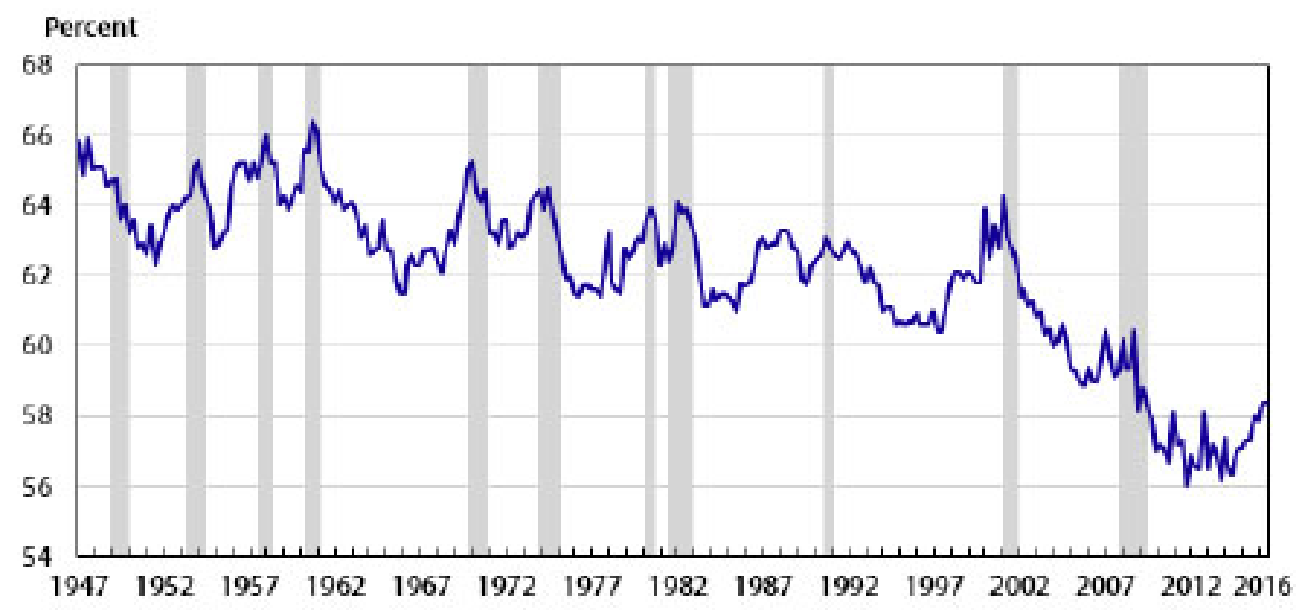

Figure 1. Labour's share of output in the non-farm business sector, first quarter of 1947 through to the third quarter of 2016. Note: shaded areas indicate recessions, as determined by the National Bureau of Economic Research. (Source: US Bureau of Labor Statistics.) 
Additionally, a sophisticated new empirical literature has begun to assess: (i) the extent to which technological developments account for a declining labour share (e.g., Autor \& Salomons 2018) and/or (ii) the relative success of low labour-share firms in capturing a disproportionate share of the relevant market (Autor et al. 2017).

Corporate governance developments would seem to provide an important explanatory channel. Over the long period in which the labour share has generally been declining, corporations have been run with decreasing levels of what might be called 'slack' - the different between current operations and an alternative that will maximise shareholder returns and shareholder value. The role of hostile bids and shareholder activism are first order in reshaping how firms are run, mostly because of the governance externalities of such interventions as they proliferate. It used to be the case that US corporations could run with 50 per cent or more slack. These are the margins that evoked hostile bids in the 1980s, a time when bidders could offer high premia even without detailed inside knowledge of a company's business. The era of hostile bids ended in the 1990s, not just because of Delaware's takeover jurisprudence but also because many management teams undertook measures to eliminate the slack that might make them a potential target. A similar process is underway in the wake of shareholder activism. Firms that formerly ran with 20 per cent slack, for example, are now vulnerable to activists who are prepared to intervene to obtain returns of 10 per cent. In response, firms now invite in teams of bankers to do an activists' style analysis of its strategy and operations so that firms can adjust pre-emptively.

A consequence of these pressures to reduce slack has been the increasingly routine lay-off of employees whose net marginal labour productivity is not positive or even whose continued employment no longer fits the current strategy. In the 1970s, for a profitable firm to lay off employees was quite rare; indeed, such an action would have been taken as sign that the firm faced serious economic troubles. This changed radically in the 1980s (Wurtzman 2017). In 1984, the US Bureau of Labor Statistics initiated its 'Displaced Worker' series, tracking incidence and consequence of lay-offs. A substantial literature documents sizable wage losses after job displacement, particularly in the case of mass lay-offs. Immediate losses in cases are roughly a third or more; long-term losses vary from approximately 15 per cent to 25 per cent, depending on the local economy (Couch \& Placzek 2010). In the current environment, wellmanaged large firms seem continuously engaged in partial downsizing. Yet for employees, finding a new job is costly, and for a meaningful fraction of employees, wage loss after re-employment will be significant. The threat of these negative effects has been an important element in restraining wage growth below the level of profit growth, particularly in the case of firms that face competitive pressure from global competitors or domestic rivals. Thus the ongoing pressure to reduce slack has systematic effects on the labour share of firms in the economy. 


\section{ECONOMIC INSECURITY}

In some circles 'globalisation' has been identified as a central source of the problems that figure in the 'malaise' (Ravallion (2018) discussing the literature). Globalisation features cross-border trade flows and cross-board capital flows. But the resulting pressures, as channelled through the corporate governance mechanism to the behaviour of firms, exemplify but hardly exhaust the persistent issues that figure in the malaise triad. Inbound global trade is the entry wedge of new competitors with products that may better match consumer tastes, provide superior innovation, or offer lower costs for equivalent goods, possibly because of a lower cost for a particular input, such as labour. To remain competitive in the market, the domestic firm must cut prices; alternatively, it may decide the cost differential is too great and it needs to close down a particular business segment. Inbound capital flows bring in investors who are focussed on economic returns and will pressure management accordingly, irrespective of the firm's place in the domestic firmament. Corporate governance is the transmission mechanism of those external pressures to the firm itself, including the rate at which the firm responds to them. But these globalisation-related economic pressures are merely examples: a domestic competitor can enter the market, using new technology that drastically lowers production costs; legislative or administrative action may reshape the competitive environment; important infrastructure changes (for example, the internet) can reshape entire distribution networks.

The common thread is that the firm has been hit with an economic shock, the consequence of which is to reduce, collectively, the value of the financial capital of shareholders and the human capital of the employees. Corporate governance may affect the allocation of those losses among shareholders and employees. Management could accept a permanent reduction in the profitability of the firm, shifting losses to shareholders, or could attempt to maintain profitability: for example, through shrinking employment (via lay-offs or attrition) or a cutback in wages (directly or through fringe benefits reductions), moves that correspondingly shift losses to employees. Management could also follow a mixed strategy.

The 'business case' presumably is a major determinant of management's response, which would include the reputational impact of its actions for retention (and morale) of current employees and recruitment of future employees. Nevertheless, 'corporate governance' is likely to affect management's actions as well. A stronger shareholder influence is likely to lead managers to minimise shareholder losses with less concern for the consequence for employees. One factor is the business feasibility of crosssubsidy from other parts of the firm for divisions that are losing their economic logic, both the extent of the cross-subsidy and its duration. Shareholder influence may express itself not just in the particular cross-subsidy decision but also in prior decisions 
that may effectively limit the cross-subsidy capacity. For example, the conglomerate form and other less extreme versions of unrelated diversification 'buoy up' not only creditors of a money-losing division but also increase the feasibility of cross-subsidy for employees. The major reason for shareholder animus towards conglomerates is skepticism about management's capacity to devise an optimal strategy and operational capacity across diverse businesses. Nevertheless a more focussed business has less cross-subsidy capacity and thus may, as a matter of economic viability, take action more rapidly even if adverse to employees.

Corporate governance may well play an important role in amplifying the adjustment costs of economic change, through its second-order effects. The liberalisation of product markets and capital markets means that firms must operate in an increasingly competitive environment. Corporate governance is the mechanism by which these competitive market pressures bear down on managerial decision-making. As noted previously in the discussions of the 'labour share', the consequence will be greater insecurity for many employees. High-powered corporate governance is likely to heighten these insecurities because the level of competitive pressure is not fixed. Efficiency-focussed shareholders may push firms to respond quickly to a changed competitive environment, unheeding of adjustment cost issues (to the extent not required by law). A rapid response by one firm in a competitive environment will evoke rapid responses from its competitors, leading to a change in the rate of economic change, an increase in the second derivative, which will greatly increase the realisation rate of adjustment costs. Note that competitive pressure may arise from private domestic firms or foreign firms, so the independent role of public firm corporate governance is uncertain.

Corporate governance could also play a role in creating economic insecurity through providing short-termist managerial incentives to enter into mergers, which commonly look to achieve 'synergies' through employee lay-offs. As discussed above, golden parachutes provide especially high immediate pay-offs to managers and thus may give managers incentives to enter into mergers. Mergers have a mixed record on lay-offs (Kuvandikov 2014). Even where net employment change is positive, meaning net growth in employment, lay-offs are common (Foley 2016). In light of the significant income losses for displaced employees, as discussed previously, mergers contribute to economic insecurity for employees. Golden parachute incentives to promote mergers are thus implicated. The irony is that the Delaware courts' anti-hostile bid jurisprudence, designed to slow the pace of a disruptive merger market (Gordon 1991), has produced governance devices like high levels of stock-based pay and golden parachutes that both increase inequality and add to economic insecurity.

One way to frame the underlying problem is in terms of changes in relative risk-bearing between shareholders and employees. The expansion of diversification 
opportunities has reduced the level of firm-specific risk borne by shareholder of public companies. Shareholders favour policies that foster economic growth and increased returns across a portfolio of companies, not at a single firm. Diversification means that shareholders will favour risk-taking by single firms. Employees, by contrast, tend to make extensive firm-specific investments that are hard to diversify. Diversification opportunities may have grown for shareholders; not so for employees.

Such poorly diversifiable investments invite insurance schemes. A public company cannot credibly issue such insurance, however. What would be the 'premium' for such insurance? Reduced current wages in exchange for a long-term employment commitment? This could result in a separating equilibrium in which the firm-employee match takes account of employees' firm-specific investment and risk-bearing preferences. In the absence of explicit contractual protection, however, such an arrangement would be vulnerable to the corporate governance prerogatives of shareholders.

But the most serious problem is that the threat to specific employee investments is external: Changing technology, changing customer tastes, and/or poor strategic decisions may undercut the competitive viability of the firm and may erode or eliminate the value of prior firm-specific investments. No firm can credibility insure against economic reversal from external competitive pressure. General Motors is a classic case. Its pension arrangements and retiree health insurance became a threat to the viability of the firm in the 1980s, because of severe recessions, a rapid increase in oil prices that shifted consumer preferences to smaller cars that it was ill equipped to produce, and external pressure from Japanese and German automobile manufacturers. Indeed, a match between risk-avoiding employees and an insurance-writing firm may have the perverse effect of producing a firm that will compete less well and thus provide less security for the employees who selected it for that reason. In general, the shareholders' exercise of governance rights is the transmission mechanism rather than the underlying cause of economic insecurity.

\section{SLOW ECONOMIC GROWTH}

Some have asserted that the slow growth rate is at least partially the result of underinvestment by public corporations, which is in turn the consequence of 'short-termism.' The evidence offered for this proposition is the high level of stock buy-backs and purported cutbacks in $\mathrm{R} \& \mathrm{D}$ either in direct response to activist shareholder pressure or in anticipatory avoidance. There may well be a special class of firms that cannot appropriately educate the market about its first-best prospects and thus could be managed 'myopically' (Stein 1998). This is how a governance innovation, like a wellspecified Board 3.0 option, could improve economic outcomes. But the absence of 
this alternative hardly accounts for 'slow growth', particularly when PE take-private alternatives are available.

Careful work by Fried and Wang (2018a, 2018b) rebuts the notion that stock buy-backs are depriving firms of funds that otherwise could go into R\&D or highvalue business projects (see also Roe 2018). Fried and Wang point out that most of the polemical claims about stock buy-backs fail to net out new equity issuances. When the proper calculations are done for the S\&P 500 firms, net corporate payouts to shareholders over the 2007-16 period fall from 96 per cent of net income to 50 per cent. Moreover, when the lens broadens beyond S\&P 500 firms, which may well be in the down-cycle of their growth, to smaller but more dynamic public firms, the payout fraction declines to 41 per cent of net income. Fried and Wang additionally point out that 'net income' understates a firm's capacity to pursue new opportunities, because many such pursuits - including a large amount of R\&D - are expensed under the applicable accounting rules and thus subtract from net income. As they put it: '[A] firm that spends more on R\&D will, everything else equal, have a lower net income and a higher shareholder-payout ratio.' When expensed R\&D is added back into net income, net shareholder payouts across all public firms are approximately 33 per cent of net income. In short, US public companies retain ample resources to pursue new growth opportunities. Resource availability is also evidenced through record levels of R\&D (in both absolute terms and relative to revenues) and very high levels of CAPEX (capital expenditure) and R\&D taken together. This is consistent with a recent Securities and Exchange Commission (SEC) study that examines capital formation over a similar period (SEC 2017). A recent MSCI report that closely examined stock buy-backs from an investor point of view, on the dimensions of ESG, CAPEX, R\&D, debt issuance, and valuation creation, found that 'the companies that were most actively distributing cash to their investors were also the strongest companies' (Marshall et al. 2018). For particular firms at particular moments, the pressures of shareholder-focussed corporate governance may induce firms to over-distribute and underinvest, but the data strongly suggest that this is not a systematic problem.

There are far more plausible candidate explanations for slow economic growth than corporate governance. Robert Gordon $(2012,2014,2017)$ develops a number of them, including demographic shifts, reduced educational attainment, and an increasing tax burden to service the national debt. His most notable conjecture is that the current wave of innovations is much less impactful than the technological innovations of the late 19th and early 20th centuries, which sparked a period of unusually high increases in productivity. The slower growth is the 'new normal' in the absence of transformative innovations.

Another potential causal factor for slow growth is the residual impact of the financial crisis. Researchers from the Federal Reserve Board of San Francisco have suggested 
that disruption of US financial markets significantly depressed US growth rates, pushing the recovery below the pre-crisis trend line (Barnichon et al. 2018). This explanation fits into a general objection to the theoretical coherence of 'shorttermism', given that the 'right term' for investment surely differs by industry sector and must be sensitive to the macro-economic environment. 'Long term' for Apple and for an electricity generating utility are hugely different. Managements and shareholders can disagree about the 'right term' for the given firm without a presumption that managers are necessarily correct. Moreover, the 'right term' for a private firm needs to take account of a macro-economic environment in which actions by governments and central banks can significantly change the level of aggregate demand and vary financial stability. Those calling for greater 'investment' by private firms seem to be using the short-term/long-term cudgel to produce a private sector stimulus programme to address a shortfall in public fiscal policymaking. If governments cannot play Keynes, perhaps inducing private firm investment can.

Of the problems in the present economic environment in which corporate governance has a role, 'slow economic growth' seems an unlikely target.

\section{SOLUTIONS WITHIN CORPORATE GOVERNANCE}

Previously this paper has sketched a new board model, Board 3.0, which would help a group of firms pursue high-value/hard-to-reveal-to-markets projects while remaining (or becoming) public companies. Instead of 'take-private' deals or 'stay private', the firms could remain public, meaning that the exceptional returns from these projects would be available to retail investors. This would enhance financial inclusion and mitigate (at the margin) some inequality concerns.

The increasing predominance of institutional owners in the United States (now roughly 75 per cent owners of most public companies) and the increasing diversification of such owners raise the possibility of a significant shift in the institutional owners' objective function. Such owners will directly face non-diversifiable risk. The build-up of socio-political pressure from the triad gives rise to a systemic risk that will affect asset prices. This may produce shareholders that are 'stability-minded' as well as 'efficiency-minded' (Gordon 2018). This may be the inchoate impulse behind stewardship codes and various campaigns against the purported 'short-termism' of hedge funds. Yet it is hard to imagine that corporate governance can produce a solution.

1. We are past the point where firms can provide sufficient social insurance or internalise the adjustment costs of economic change. That is a consequence of the changed competitive environment, in which governance mostly is accommodative. A classic example is the sharp decline in the use of the defined 
benefit pension plan. As of 1979, 38 per cent of employees in the US were covered by a defined benefit plan; by 2014, only 13 per cent were. Instead, employees were moved into a defined contribution alternative (EBRI 2014). To be sure, there is some naked risk-shifting from the firm to employees over investment risk and funding risk. Yet the interaction of its traditional payout structure (based on final salary and years worked), vesting requirements, and baseline assumption of employment stability not mobility significantly reduces the insurance value of the defined benefit plan. The risks persist, yet the firm is not well placed to internalise them.

2. Asset managers have reached their market dominance through a business model that specialises in maximum diversification at lowest cost. They can barely summon a few dozen governance specialists to produce guidelines, drop by firms on occasion, and decide how to vote in the occasional contested election. The idea of developing a social/economic policy that truly takes on system-wide questions would entail a different level of engagement (and costs).

3. The political economy of global capital markets makes it harder to develop locally based socio-economic solutions founded on corporate governance. The international nature of ownership and the fluidity of capital flows make it hard for firms to see themselves as having national responsibilities - yet all politics is national. It might be put as a multiple equilibria story: the threat of relocating operations from one country to another creates a race to the top in producing national regimes that maximise corporate (shareholder) profits, but that system can be perturbed through a local-national political reaction that shifts into an equilibrium of nationalism, mercantilism, and protectionism, which all reduce shareholder value. Shareholders collectively may have a stake in stability-enhancing measures, which might include slowing down the speed of innovation, or some amount of firm-level internalisation of adjustment costs, or firm-level provision of general human capital skills, but the corporate governance system-which focusses on maximising at the firm level and benchmarking comparative performance at the firm level, certainly encourages freeriding from the provision of such public goods.

4. Efforts to use corporate governance to rearrange distribution and riskallocation would immediately face efforts at regulatory arbitrage and evasion. For the sake of tax savings, US firms have engaged in cross-border mergers that made the foreign targets the 'survivor' in a corporate law sense: so-called 'inversion' transactions. The business stayed in place, but the corporate domicile shifted abroad, and the foreign state of incorporation set the governance rules. To assure the stability of something like co-determination against such evasion, the US would need to follow the European path of devising a 'real-seat' 
doctrine that protected the unity of a principal place of business and the corporate domiciliary. The combination of prior locational freedom and genuine questions about the appropriate corporate domicile for a multinational corporation would make it hard to run substantive change through corporate governance rules.

5. The thrust of the argument is that many of the negative effects that we observe fall into the category of the adjustment costs of economic change, or, the transition costs of capitalism. These are systemic issues. 'High-powered' corporate governance - efficiency-focussed, slack-minimising - may have played a role in transmitting changes in the competitive environment, locally and globally, to individual firms (and thus have made the environment more competitive). But corporate governance does not seem like the right tool to address the systemic issues. Corporate governance generally works on a firm-by-firm basis and thus the effort, through re-tooling corporate governance, to change the macro-environment in significant ways, will lead to endless evasions, workarounds, and freeriding. 'Stability', for example, is a property of systems, not own-firm decision-making, the domain of corporate governance.

More generally, it is important to recognise that corporations, even if 'perpetual' in the legal sense (meaning that, unlike the classic partnership, a capital supplier has no right to insist on redemption of his/her investment and a winding-up of the enterprise), are not 'perpetual' in a business sense, and we need to build systems of social protection that take account of this fact.

\section{THE GOVERNMENT 'MATCH' TO HIGH-POWERED CORPORATE GOVERNANCE}

Is there a way out of this box that does not entail a drastic change in the ownership and control of public corporations?

Here is a candidate: a reformulation in the interaction between government and the firm. At least in the US, no one would expect firms to provide employees with general or technical skills. 'Public education' is the government match, and indeed many have traced American prosperity to the decision to provide universal high school education and opportunities for advanced education (Goldin 1998). At a time when high-powered corporate governance is a complement to a competitive global environment, the national interest requires an additional complement: a strategy of lifelong entry and exit portals for training and retraining, which would be principally funded out of the gains generated by the purported efficiencies of firms managed for maximum competitive advantage. In other words, many corporate governance innovations 
have produced 'gains', but the mere satisfaction of the Kaldor-Hicks criterion, while perhaps sufficient from a short-term corporate governance perspective, may not be sufficient from a sustainable corporate governance perspective. If a Kaldor-Hicks efficient regime produces systematically biased outcomes - meaning, a consistent set of losers and winners - then it is likely that the losers will rebel against the regime. The resulting instability will degrade the regime even for the systematic winners. A populist proposal like Senator Warren's co-determination proposal is an example. Even if its implementation would reallocate the distribution of enterprise rents, it is also likely to reduce the overall level; shareholders will be worse off, but it is far from clear that employees will be better off.

This then is the backdrop for this paper's proposal for a new form of 'match' between the government and private sector enterprise. It has been customary to expect that core human capital investments - literacy, numeracy, and advanced training in many sub-disciplines - will be provided, funded, or otherwise subsidised by government. See Figure 2. This government subsidy for training that in many cases could be provided by private firms has complementary power within the overall economic system. Among other features, what might be thought of as the 'public endowment' in human capital development gives employees freedom to choose careers and life plans and provides an initial allocation of bargaining power. Changes in the economic environment argue for an ongoing match between the government and productive enterprise, a replenishing of this endowment, a match that focusses on the possibilities for re-education and retraining over a lifetime. As Figure 2 shows, most of these

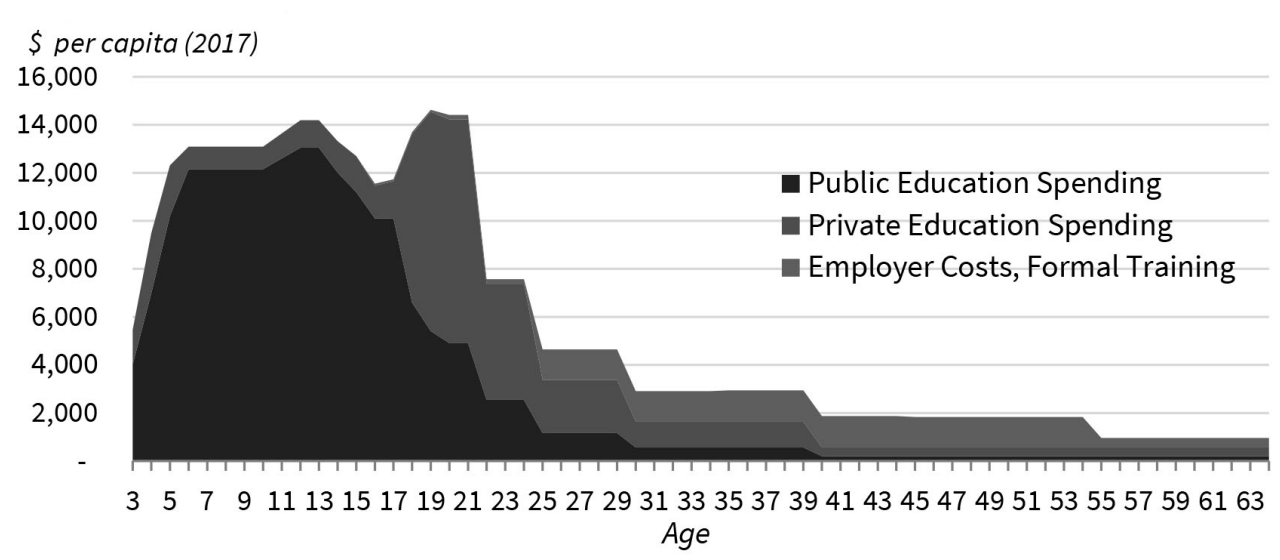

Figure 2. Expenditure on education and skills training, by age and source. (Source: CEA 2018: 1). 
expenditures have been heavily front-loaded. Those investments are obviously important, but they are insufficient in light of the economy we have. (For a useful discussion of some of the non-trivial practical challenges in providing this sort of 'reskilling' see CEA (2018).)

Government subsidy on this dimension can be thought of as a new kind of insurance, one that addresses the risk of skills obsolescence, a modern form of dis-ability, 'human capital insurance'. Firms will have limited capacity to provide this kind of insurance; most individuals will be unable to self-insure against this risk. This is a kind of risk that calls out for socialisation. The modern technology of risk diversification has given shareholders protection against firm-specific risks. Shareholders can benefit from growth in the economy as a whole, irrespective of whether particular firms are diminished or even survive. Employees simply cannot effectively diversify against these risks, and attention must be paid.

It is important to emphasise that this kind of insurance benefits the shareholders as well as employees who are directly insured. The basis for the risk-shift between employees and shareholders is the low-cost diversification that shareholders have access to. The shareholders hold the minimal-cost diversification products devised by the asset managers. These products eliminate firm-specific risk, protecting shareholders even while exposing employees. The only way to improve the performance of such investments is by improving returns across the economy as a whole or by lowering systematic risk. The insistence on running firms to maximise shareholder value is grounded in the belief that this will promote better resource allocation and superior economic performance, across the entire portfolio.

Neoclassical theory argues that a firm should be managed in this way so as not to waste scare resources, whether capital or labour. On this view, lay-offs not only reduce costs for the instant firm; they permit the reallocation of scarce labour resources to higher and better uses. We know that real-world frictions and shocks stand in the way of this seamless reallocation. Economic geography is sometimes harsh: a small community-leading business match that had great complementarities in one moment will also leave employees highly exposed to changing economic circumstances. Skills that were highly prized in one moment may be rendered obsolete by technology at another moment. A 'human capital insurance' scheme, by protecting the ongoing productive capacity of employees, notwithstanding the churn of a dynamic economy, will increase expected returns across the economy. In this regard, there is less conflict between shareholders collectively and employees collectively than is commonly thought. Moreover, since the political economy on which the shareholder governance model rests depends upon acquiescence, if not support, by the non-shareholder majority, this human capital insurance should reduce a source of systematic risk. This directly benefits diversified shareholders by improving risk-adjusted returns. 
This point can be framed differently, in way that makes clear that this proposal does not collapse into a call for redistribution, or simply an effort to assure that gains that increase the whole pie do not result in smaller slices for many. Rather: One of the explanations for the low economic growth rate is adverse demography. The percentage of the working population is declining relative to those who are living longer; this produces an increasing mismatch between tax receipts and the payout of retirement income and health benefits. Enhancing the ongoing productive capacity of people is one way to enlarge the labour force. The classic defence of downsizing and lay-offs is not that they increase shareholder value for the particular firm. Instead, they free up scarce resources for firms that put those resources to better use. Given the practical barriers to seamless switching in the labour market, including particularly the specialised training that many good jobs require, a lifetime re-education and retraining programme offers the promise of high dividends. As a strategy, 'Invest in our People' is one way out of the malaise.

Could asset managers be a mobilising source of support for such a measure? As observed previously, the asset managers' product is a low-cost diversified portfolio of securities, which will necessarily eliminate firm-specific risk. The way to improve performance for the users of such products is to increase expected returns across the portfolio and/or to reduce systematic risk. It must be the case that asset managers believe that 'high-powered corporate governance', which reduces slack and leads to lay-offs, will increase returns across the portfolio of firms: that is, across the broad economy, even with the consequent under-utilisation of human potential. The risk (for them/for the diversified investor) is that resulting pattern of gains and losses threatens the political consensus that undergirds this regime. So a better government 'match' to employment turbulence in a gains-seeking economy is good for them/their clients because: (i) it adds to returns across the economy; (ii) it reduces the systematic risk of backlash. Yet asset managers might well hesitate in taking a leadership role in advancing a policy measure. Public pension funds and sovereign wealth funds will have more freedom of initiation and advocacy. 'Rationally reticent' asset managers might join in as endorsers.

Global capital markets threaten the national capacity to adhere to the particular national bargain struck over the allocation of enterprise gains. The analogy is to the financial crisis of 2007-9, in which the Federal Reserve lost its capacity to control the US real-estate bubble. The inflow of foreign debt finance broke the link between the Fed's tool - the raising of short-term interest rate-and long-term rates, the critical financing variable for mortgage finance (Bernanke et al. 2011, Tooze 2018). Similarly, the international flow of equity capital seeking highest returns adds to the volume of institutional investor funds with similar objectives. A national strategy aimed at enhancing the human capital of the citizenry becomes a way of reasserting 
national control over these enterprise gains because it creates the foundation for durable national advantage.

A funding approach falls out of this strategy as well. As the race to the bottom in corporate tax rates across the OECD demonstrates, it is hard to tax capital. This argues for a consumption-based tax, not to induce additional investment but to impose tax incidence on the least mobile feature of the benefits-receiving chain. That is, part of the argument for the high-powered governance model is that it yields lower cost/higher quality goods and services; meaning it increases consumer surplus. An appropriately designed consumption tax (with carve-outs that are appropriate in light of distributional objectives) can thus be a way of using some of the gains to fund the complementary insurance scheme.

\section{REFERENCES}

Acharya, Viral \& Volpin, Paolo (2010), 'Corporate Governance Externalities', Review of Finance, 14: 1-33. https://doi.org/10.1093/rof/rfp002

Adams, Zoe \& Deakin, Simon (2018), 'Corporate Governance and Employment Relations', in Jeffrey Gordon \& Wolf-Georg Ringe (eds) Oxford Handbook of Corporate Law and Governance (Oxford, Oxford University Press), 1037-62.

http://www.oxfordhandbooks.com/view/10.1093/oxfordhb/9780198743682.001.0001/oxfordhb9780198743682-e-44

Armour, John \& Gordon Jeffrey (2014), 'Systemic Harms and Shareholder Value', Journal of Legal Analysis, 6 (1): 35-85. https://academic.oup.com/jla/article/6/1/35/933345;

https://doi.org/10.1093/jla/lau004

Autor, David \& Salomons, Anna (2018), 'Is Automation Labor-displacing? Productivity Growth, Employment, and the Labor Share', working paper 24871, National Bureau of Economic Research, Cambridge, MA.http://www.nber.org/papers/w24871; https://doi.org/10.3386/w24871

Autor, David, Dorn, David, Katz, Lawrence F., Patterson, Christina \& Van Reenen, John (2017), 'The Fall of the Labor Share and the Rise of Superstar Firms', working paper 23396, National Bureau of Economic Research, Cambridge, MA. http://www.nber.org/papers/w23396.

Barnichon, Regis, Matthes, Christian \& Ziegenbein, Alexander (2018), 'Are the Effects of Financial Market Disruptions Big or Small?', working paper, Federal Reserve Board of San Francisco, 7 June.

Bebchuk, Lucian \& Fried, Jesse (2004), Pay Without Performance: The Unfulfilled Promise of Executive Compensation (Cambridge, MA, Harvard University Press). https://papers.ssrn.com/sol3/papers.cfm?abstract_id=537783

Bernanke, Ben, Bertaut, Carol, Pounder DeMarco, Laurie \& Kamin, Steven (2011), 'International Capital Flows and the Returns to Safe Assets in the United States, 2003-2007', International Finance discussion papers 1014, Board of Governors of the Federal Reserve System, February. https://www.federalreserve.gov/pubs/ifdp/2011/1014/ifdp1014.pdf

CEA (2018), 'Addressing America's Reskilling Challenge', Council of Economic Advisers ,17 July. https://www.whitehouse.gov/wp-content/uploads/2018/07/Addressing-Americas-ReskillingChallenge.pdf 
Choi, Albert, Lund, Andrew \& Schonlau, Robert (2018), 'Shareholder Voting on Golden Parachutes: Determinants and Consequences', Law and Economics paper 2018-13, University of Virginia School of Law, 15 August.https://papers.ssrn.com/sol3/papers.cfm?abstract_id=3229962

Couch, Kenneth \& Placzek, Dana (2010), 'Earnings Losses of Displaced Workers Revisited', American Economic Review, 100(1): 572-89.

http://www.aeaweb.org/articles.php?doi=10.1257/aer.100.1.572;

https://doi.org/10.1257/aer.100.1.572

Dao, Mai Chi, Das, Mitali, Koczan, Zsoka \& Lian, Weicheng (2017), 'Why Is Labor Receiving a Smaller Share of Global Income? Theory and Empirical Evidence', working paper WP/17/169, International Monetary Fund, Washington, DC.

https://www.imf.org/en/Publications/WP/Issues/2017/07/24/Why-Is-Labor-Receiving-a-SmallerShare-of-Global-Income-Theory-and-Empirical-Evidence-45102

EBRI (2014), 'FAQs About Benefits-Retirement Issues', Employee Benefits Research Institute. https://www.ebri.org/publications/benfaq/index.cfm?fa=retfaq14

Edmans, Alex \& Gabaix, Xavier (2016), 'Executive Compensation: A Modern Primer', Journal of Economic Literature, 54: 1232-87. https://doi.org/10.1257/jel.20161153

Foley, John (2016), 'Merger "synergies" can’t just be code for job cuts', Breakingviews (blog), Reuters, 8 June.

http://blogs.reuters.com/breakingviews/2016/06/08/merger-synergies-cant-just-be-code-for-job-cuts/

Fried, Jesse (2011), 'Share Repurchases, Equity Issuances, and the Optimal Design of Executive Pay', Texas Law Review, 89: 1113-47. https://papers.ssrn.com/sol3/papers.cfm?abstract_id=1845620; https://doi.org/10.2139/ssrn.1873414

Fried, Jesse \& Charles Wang (2018a), 'Are Buybacks Really Shortchanging Investment?', Harvard Business Review, (March-April): 88-95.

https://hbr.org/2018/03/are-buybacks-really-shortchanging-investment

Fried, Jesse \& Charles Wang (2018b), 'Short-termism and Capital Flows', Working Paper Series in Law, 342/2017, European Corporate Governance Institute, Brussels.

http://ssrn.com/abstract_id=2895161

Giandrea, Michael \& Sprague, Shawn (2017), 'Estimating the U.S. Labor Share', Monthly Labor Review, February, US Bureau of Labor Statistics, Washington, DC. https://doi.org/10.21916/mlr.2017.7

Gilson, Ronald (2018), 'From Corporate Law to Corporate Governance', in Jeffrey N. Gordon \& WolfGeorg Ringe (eds) Oxford Handbook of Corporate Law and Governance (Oxford, Oxford University Press), 3-27. https://papers.ssrn.com/sol3/papers.cfm?abstract_id=2819128

Gilson, Ronald \& Jeffrey Gordon (2013), 'The Agency Costs of Agency Capitalism: Activist Investors and the Re-valuation of Governance Rights', Columbia Law Review, 113: 863-928.

https://law.stanford.edu/wp-content/uploads/sites/default/files/publication/662901/doc/slspublic/ Gilson-Gordon.pdf

Gilson, Ronald \& Jeffrey Gordon (2018), 'Board 3.0', working paper.

Goldin, Claudia (1998), 'America's Graduation from High School: The Evolution and Spread of Secondary Schooling in the Twentieth Century', Journal of Economic History, 58: 345-74. https://doi.org/10.1017/S0022050700020544

Gordon, Jeffrey (1991), 'Corporations, Markets, and Courts', Columbia Law Review, 91: 1931-88. https://doi.org/10.2307/1123036

Gordon, Jeffrey (1998), 'Employee Stock Ownership in Economic Transitions: The Case of United Air Lines', Bank of America Journal of Applied Corporate Finance, 63(2).

https://papers.ssrn.com/sol3/papers.cfm?abstract_id=169028;

https://doi.org/10.1111/j.1745-6622.1998.tb00308.x

Gordon, Jeffrey (2003), 'The United Airline Bankruptcy and the Future of Employee Ownership', Employee Rights and Employment Policy Journal, 7: 227.

https://papers.ssrn.com/sol3/papers.cfm?abstract_id=809285 
Gordon, Jeffrey (2005), 'Executive Compensation: If There is a Problem, What's the Remedy? The Case for "Compensation Discussion and Analysis"', Journal of Corporation Law, 30: 675-702. https://papers.ssrn.com/sol3/papers.cfm?abstract_id=686464

Gordon, Jeffrey (2007), 'The Rise of Independent Directors in the United States, 1950-2005: Of Shareholder Value and Stock Market Prices', Stanford Law Review, 59: 1465-568. http://www.stanfordlawreview.org/wp-content/uploads/sites/3/2010/04/Gordon.pdf

Gordon, Jeffrey (2018), 'Convergence and Persistence in Corporate Law and Governance', in Jeffrey N. Gordon \& Wolf-George Ringe (eds) Oxford Handbook of Corporate Law and Governance (Oxford, Oxford University Press), 1037-62. https://ssrn.com/abstract=3037113

Gordon, Robert (2012), 'Is U.S. Economic Growth Over? Faltering Innovation Confronts the Six Headwinds', working paper 18315, National Bureau of Economic Research, Cambridge, MA. https://papers.ssrn.com/sol3/papers.cfm?abstract_id=2133145; https://doi.org/10.3386/w18315

Gordon, Robert (2014), 'The Demise of U.S. Economic Growth: Restatement, Rebuttal, and Reflections', working paper 19895, National Bureau of Economic Research, Cambridge, MA. http://www.nber.org/papers/w19895; https://doi.org/10.3386/w19895

Gordon, Robert (2017), The Rise and Fall of American Growth: The U.S. Standard of Living since the Civil War (Princeton, NJ, Princeton University Press). https://doi.org/10.1515/9781400888955

Guvenen, Fatih \& Greg Kaplan (2017), 'Top Income Inequality in the 21st Century: Some Cautionary Notes', working paper 23321, National Bureau of Economic Research Cambridge, MA. http://www.nber.org/papers/w23321.pdf

Hartzell, Jay C., Ofek, Eli \& Yermack, David (2004), 'What's In It for Me? CEOs Whose Firms are Acquired', Review of Financial Studies, 17(1): 37-61. https://doi.org/10.1093/rfs/hhg034

Holmstrom, Bengt (1979), 'Moral Hazard and Observability', Bell Journal of Economics, 10(1): 74-91. https://doi.org/10.2307/3003320

Kahneman, Daniel \& Twersky, Amos (1979), 'Judgment under Uncertainty: Heuristics and Biases', Science, 185(4157): 1124-31.https://doi.org/10.1126/science.185.4157.1124

Kaplan, Steven (2012), 'Executive Compensation and Corporate Governance in the U.S.: Perceptions, Facts and Challenges', working paper 18395, National Bureau of Economic Research, Cambridge, MA.http://faculty.chicagobooth.edu/steven.kaplan/research/ceogov.pdf; https://doi.org/10.3386/w18395

Keynes, John Maynard (1939), 'Relative Movement of Real Wages and Output', Economic Journal, 49: (193): 34-51. https://www.jstor.org/stable/2225182?seq=1\#metadata_info_tab_contents; https://doi.org/10.2307/2225182

Kuvandikov, Azimjon, Pendleton, Andrew \& Higgins, David (2014), 'Employment Change after Takeovers: The Role of Executive Ownership', British Journal of Industrial Relations, 52: 191236. https://papers.ssrn.com/sol3/papers.cfm?abstract_id=2434819; https://doi.org/10.1111/bjir.12012

Marshall, Ric, Seretis, Panos \& Grunfeld, Agnes (2018), 'Taking Stock: Share Buybacks and Shareholder Value', MSCI ESG Research, based on Thomson Reuters data, retrieved from Harvard Law School Forum on Corporate Governance and Financial Regulation (blog), 19 August. https://corpgov.law.harvard.edu/2018/08/19/taking-stock-share-buybacks-and-shareholder-value/

Murphy, Kevin (2013), 'Executive Compensation: Where We Are, and How We Got There', in George M. Constantinides, Milton Harris \& Rene M. Stulz (eds) Handbook of the Economics of Finance, vol 2A (Amsterdam, Elsevier/North-Holland) 211-356.

https://doi.org/10.1016/B978-0-44-453594-8.00004-5

Piketty, Thomas (2014), Capital in the 21st Century (Cambridge, MA, Harvard University Press).

Piketty, Thomas, \& Saez, Emmanuel (2003), 'Income Inequality in the United States, 1913-1998', Quarterly Journal of Economics, 118(1): 1-39. http://www.jstor.org/stable/25053897; https://doi.org/10.1162/00335530360535135 
Piketty, Thomas, Saez, Emmanuel \& Zucman, Gabriel (2018), 'Distributional National Accounts: Methods and Estimates for the United States', Quarterly Journal of Economics, 133: 553-609. http://www.nber.org/papers/w22945.pdf; https://doi.org/10.1093/qje/qjx043

Preqin (2018), 'Preqin Quarterly Update: Private Equity \& Venture Capital Q2 2018'.

http://docs.preqin.com/quarterly/pe/Preqin-Quarterly-Private-Equity-Update-Q2-2018.pdf

Ravallion, Martin (2018), 'Inequality and Globalization: A Review Essay', Journal of Economic Literature, 56: 620-42.https://doi.org/10.1257/jel.20171419

Roe, Mark (2018), 'Stock Market Short-Termism's Impact', 13 August.

https://papers.ssrn.com/sol3/papers.cfm?abstract_id=3171090

Saez, Emmanuel (2008), 'Striking It Richer: The Evolution of Top Incomes in the United States', Pathways Magazine, Stanford Center for the Study of Poverty and Inequality, 15 March. https://eml.berkeley.edu/ saez/saez-UStopincomes-2006prel.pdf

SEC (2017), 'Access to Capital and Market Liquidity', staff report, Securities and Exchange Commission Division of Economic and Risk Analysis, August.

Smith, Matthew, Yagan, Danny, Zidar, Owen \& Zwick, Eric (2017), 'Capitalists in the Twenty-first Century', 15 November. https://bfi.uchicago.edu/sites/default/files/research/capitalists.pdf

Stein, Jeremy (1988), 'Takeover Threats and Managerial Myopia', Journal of Political Economy, 96(1): 61-80. https://dash.harvard.edu/handle/1/3708937; https://doi.org/10.1086/261524

Thomas, Randall (2009), 'International Executive Pay: Current Practices and Future Trends', in Labor and Employment Law and Economics Kenneth Dau-Schmidt, Seth Harris \& Orly Lobel (eds) (Cheltenham, Edward Elgar). https://papers.ssrn.com/sol3/papers.cfm?abstract_id=1265122

Thomas, Randall \& Wells, Harwell (2011), 'Executive Compensation in the Courts: Board Capture, Optimal Contracting, and Officers' Fiduciary Duties', Minnesota Law Review, 95: 846-903.

http://www.minnesotalawreview.org/wp-content/uploads/2013/05/ThomasWells_PDF.pdf

Tooze, Adam (2018), Crashed: How a Decade of Financial Crises Changed the World (New York, Viking). US Congress. Senate. Accountable Capitalism Act. S. 3348. 115th Cong., 2nd sess. Introduced in Senate 15 August. https://www.congress.gov/bill/115th-congress/senate-bill/3348/text

Wartzman, Rick (2017), The End of Loyalty (New York, Public Affairs).

Wolff, Edward (2010), 'Recent Trends in Household Wealth in the United States: Rising Debt and the Middle-Class Squeeze-An Update to 2007', working paper 589, Levy Economics Institute, Bard College, Annandale-on-Hudson, NY. http://ssrn.com/abstract=1585409

Note on the author:

Jeffrey N. Gordon is the Richard Paul Richman Professor of Law at Columbia Law School, Visiting Professor in the Law Faculty of the University of Oxford, and a Fellow of the European Corporate Governance Institute. He is co-director of Columbia Law School's Millstein Center for Global Markets and Corporate Ownership as well as co-director of the Richman Center for Business, Law and Public Policy. Professor Gordon teaches and writes extensively on corporate law and governance, mergers and acquisitions, comparative corporate governance, and, more recently, the regulation of finance institutions. He is the co-editor of The Oxford Handbook on Corporate Law and Governance (OUP, 2018) and co-author of Principles of Financial Regulation (OUP, 2016). One article particularly relevant to recent debates is: 'The Agency Costs of Agency Capitalism: Activist Investors and the Re-valuation of Governance Rights' (Columbia Law Review, 2013, with Ronald Gilson). 
To cite the article: Jeffrey N. Gordon (2018), 'Is corporate governance a first-order cause of the current malaise?', Journal of the British Academy, 6(s1): 405-436. DOI https://doi.org/10.5871/jba/006s1.405

This article is licensed under a

Creative Commons Attribution-NonCommercial-NoDerivs 4.0 Unported License.

Journal of the British Academy (ISSN 2052-7217) is published by

The British Academy - the national academy for the humanities and social sciences.

10-11 Carlton House Terrace, London, SW1Y 5AH

www.britac.ac.uk 